\title{
Shaping the Orgnisational Culture to Improve the Teachers' Commitments in Islamic School (A Case Study at SMA Muhammadiyah 1 Gresik)
}

\author{
Taufiqulloh \\ Postgraduate Student, Universitas Negeri Surabaya \\ Surabaya, Indonesia \\ Mukhlas Samani \\ Education Management, Universitas Negeri Surabaya \\ Surabaya, Indonesia \\ Murtadlo \\ Education Management, Universitas Negeri Surabaya (State University of Surabaya) \\ Surabaya, Indonesia
}

\begin{abstract}
This study was aimed at knowing the unique phenomena about the factors of shaping the organisational culture to increase the teachers' commitment in an Islamic school. The study used a survey design. The study used a questionnaire to collect the data. The results of this study showed that there were seven factors of shaping the organisational culture at SMA Muhammadiyah 1 Gresik including belief, value, language, legend, climate, ritual, and physical structure. Furthermore, those factors of shaping the organisational culture could afford to contribute to the increase of the teachers' commitments.
\end{abstract}

Keywords: Organisational culture, teachers' commitment, islamic school.

DOI: $10.7176 / \mathrm{JEP} / 10-18-11$

Publication date:June $30^{\text {th }} 2019$

\section{INTRODUCTION}

One of the factors supporting the school success is the existence of the organizational culture applied by each individual of school member. It is because the organizational culture has significant roles to improve the school conditions through the increase of the teachers' commitments in working so that it can support the school development or success.

Some previous researchers found that the organizational culture gave a positive impact to the increase of the school member performance and productivity so that it could increase the school achievements and quality (James \& Nyongesa, 2012; Hilman \& Siam, 2014).

The shaping of the organizational culture cannot be separated from the factors shaping one model of the organizational culture. According to McShane\& Von Gillnow (2005). The factors shaping the organizational culture consists of belief, value, language, legend, ritual activity, climate, and physical structure. All those factors above are assumed to be the basic foundations in shaping the certain or specific characters performed by each individual in order to create organizational culture form expected in accordance with visions, missions, and goals of the organization or school developed

Schein (1992) exclaims that the organizational culture encompasses the basic assumptions and values that must be accepted by each individual of an organization in order that the organization can still exist and develop. In line with the statement above, Robbins (1998) states that the organizatioal culture is a meaningful system kept together by all individuals to differentiate one organisation from others. McShane and Von Gilnow (2005) also state that organisational culture is supposed to be the basic patterns of various assumptions, values, and beliefs which can be considered as the right way of thinking and acting to face some problems in an organisation.

Based on the explanation above, it can be explained that the culture created by a group of people can be accommodated in an organization. On the other hands, the characteristics of any organization may refer to some experiences or practices performed by individuals which can show how the organization and its behavior work. In this case, all school teachers are required to get involved in implementing the concepts of the organizational culture.

Teachers are supposed to be the primary key to determine the education quality. The education quality mainly concerns with the teaching and learning activities performed by the teachers. There are many factors of determining the qualified teeaching and learning activities. Many researches conclude that the teachers' commitments can determine the quality of the teaching and learning processes. Hence, the higher the teachers can perform their commitments in working, the better the education quality or qualified teachingand learning 
process the teachers can perform (Caprara et al, 2006: 473-490). Therefore, teachers' commitments cannot be excluded from the attention for getting the qualified education.

Commitment is defined as the high level of the relationship made by one individual to the organisation where they work (Crosswell, 2006:55). Hence, the teachers' commitments are concerned with the schools where they can work as the teachers for teaching the students (Cohen, 2003:78). Meyer and Allen (1991:61-89) propose three kinds of commitments consisting of affective, continuous, and normative commitments.

Affective commitment in education refers to the emotional, identical, and partisipatory relationships in the profession and its goal in terms of the motivation to identify and aspire to the personal likes or interests. Furthermore, it is also concerned with thinking about the contribution gained by doing the profession (Ware \& Kitsantas, 2007:303-310). In addition, Meyer and Allen (1991, p. 114-136) indicate that affective commitment are influenced by some factors like working target or challenge, the working level of difficulty, management, personal similarities, feedbacks, and personal needs.

Continuous commitmen refers to the awareness of the living cost that must be gained by leaving the profession. In this case, the employees are forced to continu e or keep their profession because they also feel to need the profession. There is instrumental colaboration between their need and commitments. This means that the commitment built is based on the economic benefits earned (Beck \& Wilson, 2000: 114-136).

Continuous commitment in education refers to the commitment based on the benefit and cost connected to the condition of staying at the organisation or profession (Nazari \& Emami 2012:10661-10664). This is the range of which the individuals believe that they must stay to work or keep their profession for teaching the studnets at schools because this profession lacks of the altervatives or possibilities of leaving the job as the teacher (Ware \&Kitsantas, 2007: 303-310). This can also be said to have no choices in getting other economic conditions besides staying to be the teacher (Maheshwari et al, 2007). The teachers with the continuous commitments will keep their professions since leaving their professionwill struggle with high living cost that they can't afford to get other alternatives.

Normative commitment depicts the feeling of obligation to continue working. The employees may feel that they must stay to work at the organisation (Meyer \& Allen, 1991:61-89). The normative belief to the job or duty makes those individuals have the responsibility to support the memberhip of the organisation.

Normative commitment in education refers to the moral responsibility owned by a person to his/her job or profession (Allen \& Meyer 1993; Ware dan Kitsantas, 2007). This is a must leading to support the profession (Maheshwari et al, 2007). The purpose of adoption to the school value leads the teachers' basic commitments to the school itself. Some variables may determine the levels of the teachers' commitments. They include the interactions among the teachers, the relationship between the teachers and their students, job quality done by the teachers, and job environment (Celep, 2000).

In short, it is possible to say that the organizational culture and teachers' commitments need to grow and develop together to open an access for the school development. However, there is still something to be considered to determine certain factors of the organizational culture which support or contribute dominantly the teachers' commitments in working to reach the success for the school development.

Based on the explanation above, the writer needed to conduct the investigation about the organizational culture to increase the teachers' commitments. Therefore, to get the focus of this study, the writer tried to formulate the research questions as follows.

1. What factors of the organizational culture do the teachers implement to increase their commitment in working at school?

2. What teachers' commitments are dominantly built through the factors of the organizational culture at school?

\section{RESEARCH METHODOLOGY}

The research used a survey design. The research was done at Muhammadiyah senior high school located in Gresik city East Java Indonesia. The research applied a stratified random sampling which involved 20 teachers of the whole population about 50 teachers as the respondents or informants.

The research also used a questionnaire which was constructed and modified by the writer himself to asw the instrument for collecting the data. The instrument was made in accordance with the demographic concepts of the survey model of 'open survey'.

The data gained were analyzed by using 'Coeficient Alpha Cronbach' pattern within the estimation of the coefficient reliability more than 0.6 showing that the instrument used had fulfilled or met the criteria of success of the research objectives.

\section{RESULTS}

The organizational culture does not grow by itself automatically. But, it needs some supporting factors which can give the access for the school members to form certain assumptions, behaviours, and mindsets. There were 
seven factors of shaping the organizational culture consisting of belief, value, legend, language, ritual activities, climate, and physical buildings.

Fig 1. Factors of shaping the organizational culture

\section{OB Shaping Factors}

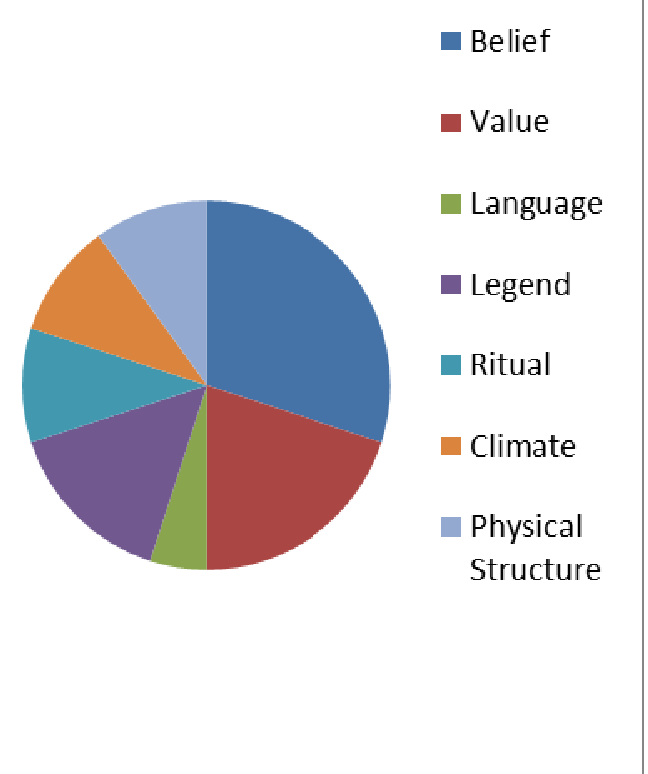

Overall, the figure above shows that the belief as one of the factors was known to be the most dominant factor shaping the organizational culture performed by the teachers at school about $30 \%$. Even though all the teachers investigated had different background, economic status, and environment, those things did not influence their assumptions, behavious, and mindsets about the shaping of the organizational culture at school.

What happened to the teachers showed one expectation to make the belief as the most dominant factor which could shape the organizational culture at school based on the Islamic values or concepts.

The figure above also showed that the least dominant factor shaping the organizational culture at school went to the language about $5 \%$. This also showed that the language as one of the factors of the organizational culture did not have big role in shaping the organizational culture at Islamic school. Language is important as a means of communication at school. However, langauge could not be the priority of shaping the organizational culture at Islamic school.

The existence of various langauges at school made it difficult to shape certain culture. This was supposed to be the weakness to see one main character of the organizational culture that could be prioritized as the factor of shaping the organizational culture there.

However, the use of various languages at school did not give some obstacles or led to emerge the conflict among the individuals. Even, it could give another colour of the different organizational culture developed from other schools. Hofstede (2001) states that one of the sosialization processes for the shaping of the organizational culture needs language as the means of arranging the mindsets and perceptions among individuals.

Meanwhile, the second figure below showed the variety of the commitment types owned by the teachers as the effects of the existence of the organizational culture at school. The types of the commitment contained about affective, normative, and continuous commitments. What happened to the type of commitment oned by the teachers showed that the affective commitment was supposed to be the most dominant commitment belonging to the teachers at the school investigated about $45 \%$.

This strengthened the evidence concerning with the belief as the dominant factor of shaping the organizational culture at school. In other words, the belief was supposed to correlate with the affective commitment which could increase the teachers' high motivations of working. What happened to the teachers at the school investigated showed that the organizational culture was successfully shaped by the belief which was based on the Islamic values or concepts. This factor was also able to entail the increase of their affective commitment through high motivation to get the improvement of their working performances.

Meanwhile, the least dominant commitment type went to the teachers' continuous commitments. In spite of the affective commitment which could grow the teachers' sincerity for working, the continuous commitment more tended to think about the economic problems. This commitment type had $15 \%$. This also showed that the teachers did not care much about the economic problems including the salary or compensation when working. However, the school investigated still had an obligation to increase the teachers' welfare better in the future. 
Fig 2. Teachers' Commitmetn Types (In Number)

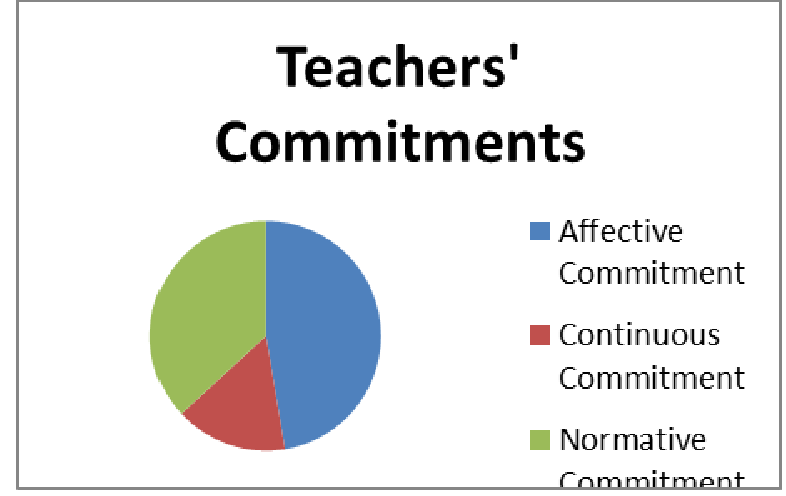

\section{DISCUSSIONS}

The phenomena of the organizational culture still remains the polemic at school. Every school will try to build the expected organizational culture maximally which can create good school prestige in society. However, the shaping of the organizational culture at school is not easy. It needs some supporting factors as the access to form the organizational culture at school.

McShane and Von Gillnow (2005) state that some important factors of the organizational culture consist of assumption, value, belief, history, ritual activities, language, and physical buildings. Those factors are assumed to be the access of shaping the expected organizational culture at school. This is because those factors of the organizational culture may contribute to the improvement and incraese of the teachers' commitments which may encompass affectice, normative, and continuous commitments.

Hence, the organizational culture and commitment are the two things that are related to each other. The findings of this study showed that belief as one of the factors of the shaping of the organizational culture gave great or significant contribution to the increase of the affective commitments at school.

Abdullah and Arokiasanny (2016) revealed that there was a positive correlation between the school culture and the job satisfaction in accordance with the teachers' perceptions. Besides, the organizational culture, statiscally, was seen to be the main factor of the job satisfaction variable performed by the school teachers. Meanwhile, Imam, Abbasi, Muneer, and Qadri (2013) found that the organizational culture gave a positive impact to the incease of the individual readiness to the changes. In this case, the organizational culture was able to create the individual creativity and productivity which were beneficial to support the organization performances.

\section{CONCLUSION}

One important thing that can be taken as the conclusion of this study was that the existence of the organizational culture became the main factor of the increase of the teachers' commitments at school. Specifically, the organizational culture had been successful in creating one pattern of the mindset and behaviour of shaping the personal characters within full of high motivation and sincerity in accomplishing their jobs well.

This study revealed that there existed the teachers' tendency to grow their affective commitments as the influcnce given by the organizational culture through the belief derived from the Islamic values. Hence, it was expected that the developed organizational culture could make the changes to no only the individual mindset, but also behaviour which affected to the increase of their achievements and performances at school.

\section{ACKNOWLEDGEMENT}

The writer's special gratitude go to Prof. Dr. Mukhlas Samani, M.Pd whose instigation has inspired and enthused the writer to keep writing and convinced the writer to be strong, patient, and confident in analyzing the data of the research. The writer's second special gratitude go to Prof. Dr. Murtadlo, M.Pd whose pedagogical contributions for discussing any concepts to get the improvements of the writer's knowledge and skills in completing the research. The great thanks also go to Ainul Muttaqin, SP as the headmaster of SMA Muhammadiyah 1 Gresik who has given the writer permission and opportunity to conduct the research and investigation.

\section{REFERENCES}

Abdullah, Abdul Ghani K. \& Arokiasamy, Anantha R. (2016). The influence of school culture organizational health of secondary school teachers in Malaysia. TEM Journal, 2(5), pp. 56-59.

Beck, N.M. \& Wilson, J.H. (2000). Development of affective organizational commitment: Across-sequential examination of change. .Journal of Vocational Behavior. 56,114-136. 
Caprara,G.V.,Barbaranelli,C.,Steca,P,\&Malone,P.S.(2006).Teachers'self-efficacy beliefs as determinants of jobs at is faction and students' academic achievement: A study at the school level. Journal of School Psychology, 44, 473-490.

Cohen, A. (2003). Multiple Commitments in the Workplace: An integrative approach. Mahwah, NJ: Erlbaum.

Creswell, L. (2006). Understanding Teacher Commitment in Times of Change. Doctoral Thesis.

Hilman, Haim. \& Siam, Mohammed. (2014). The influence of organisational structure and organizational culture on the organizational performance of higher educational institutions: The moderating role of strategy communication. Asian Social Science Journal, 10(13), pp. 142-154.

Hofstede, Geert. (2001). Culture's consequences. ( $2^{\text {nd }}$ ed.) Thousand Oaks, London: New Delhi Press.

James, Muya. \& Nyongesa, W.J. (2012). The impact of organizational culture on perfromance of educational institutions. International Journal of Business and Social Science, 3(8), pp. 211-217.

Maheshwari, S., Bhat, R., \&, A. (2007).Implications of human resource practices and other structural factors on commitment of public medical professionals. India. Retrieved October 22.

McShane, Steven L. \& Von Gilnow, M.A. (2005). Organizational behavior. New York: McGraw Hill.

Meyer, J.P. \&Allen, N.J. (1991).A three component conceptualization of organizational commitment. Human Resource Management Review, 1, 61-89.

Nazari, K. \&Emami, M. (2012).Analysis of relation between organizational commitment and professional commitment. Elixir Human Res. Mgmt. 51(2012)10661-10664. Retrieved August 20, 2013.

Robbins, G. (2001). Organizational behavior ( ${ }^{\text {th }}$ Edition). San Fransisco, CA: Prentice Hall.

Schein, Edgar H. (2004). Organizational culture and leadership ( $3^{\text {rd }}$ ed.). Sanfransisco, CA: John Wiley \& Sons.

Ware, H., \& Kitsantas, A. (2007). Teachers and collective efficacy beliefs as pedictors of professional commitment. Journal of Educational Research, 100(5), 303-310. Retrieved November8, 2010, from Academic Source Premier database. 